Vol 1 No 22020 Desember 2020

Jurnal AlphaEuclidEdu

Received: 25/11/2020; Revised: 30/11/2020; Accepted: 05/12/2020

\title{
IMPLEMENTASI SISTEM PEMBELAJARAN DARING BERBANTUAN EDMODO PADA MAHASISWA
}

\author{
Mirza, Ade \\ Dosen Pendidikan Matematika FKIP Universitas Tanjungpura Pontianak \\ Email: ade.mirza@fkip.untan.ac.id
}

\begin{abstract}
This research is a case study which aims to examine and describe the learning independence, learning outcomes, and student responses to the implementation of lectures with the edmodo-assisted online learning sistem. The subjects of this study were 142 students of the Mathematics education program FKIP Untan Pontianak in 2020 that who programmed the differential calculus course. This research activity in the process involves three senior students as collaborators (research assistants). Lecture practice is carried out by the lecturer who teaches these courses. This research procedure consists of: (1) reviewing the material, preparing research tools and instruments (developing and standardizing instruments). (2) Conducting lectures using the online learning sistem assisted by Edmodo. (3) Distributing questionnaires to obtain independence data, providing learning outcomes tests, and providing questionnaires to get student responses to the implementation of learning - (data collection). (4) Conduct studies and interpretations of the data obtained. (5) Reporting. The results of this study indicate that the learning independence of students in lectures is still not satisfactory. Student responses to the learning sistem were 57.04\% giving positive responses, and $42.96 \%$ giving negative responses. For learning outcomes, $74.65 \%$ were able to achieve a score $\geq 70$ and no one got a score less than 60 . In this case $57.75 \%$ got a $B$ grade and $16.90 \%$ got an A. It is clear that learning with the edmodo-assisted online sistem is able to make a fairly good contribution to differential calculus lectures.
\end{abstract}

Key words: Calculus, Independence learning, Mathematics.

\section{Pendahuluan}

Agenda utama dalam reformasi pendidikan Matematika dan Ilmu Pengetahuan Alam (MIPA) dewasa ini, di antarnya adalah penekanan pada pentingnya mengembangkan keterampilan berpikir tingkat tinggi mahasiswa calon guru. Upaya pengembangan kapasitas intelektual tersebut dimaksudkan agar mereka siap dihadapkan pada transisi pengetahuan dan arus informasi yang semakin deras serta mampu beradaptasi dan menyerap informasi yang dibutuhkan (AACTE, 2010). Sejalan dengan hal ini, sejumlah laporan nasional di berbagai negara dalam kurun waktu 20 tahun terakhir telah menunjukkan bahwa desain pembelajaran untuk menstimulasi proses berpikir dan pemecahan masalah serta menghasilkan solusi yang kompleks menjadi sangat dibutuhkan (Halpern, 2003; Zohar, Degani \& Vaaknin, 2001; Moseley, et.all, 2005), 
Vol 1 No 22020 Desember 2020

Jurnal AlphaEuclidEdu

Received: 25/11/2020; Revised: 30/11/2020; Accepted: 05/12/2020

agar pemelajar mampu beradaptasi terhadap setiap perubahan (Halpern, 2003), memperoleh pengetahuan baru secara lebih cepat, dan menghadapi kompleksitas permasalahan nyata di dalam kehidupan (King, Goodson \& Rohani, 2006).

Diakui bahwa, matematika merupakan salah satu subyek pengetahuan yang penting dalam kehidupan manusia dan merupakan body dari sains dan teknologi (Acharya, 2017). Kalkulus misalnya, merupakan salah satu mata kuliah dasar yang sangat penting bagi mahasiswa matematika di universitas. Namun demikian, masih banyak pemelajar (mahasiswa) yang tidak dapat mencapai pemahaman ataupun pengertian yang mendalam (understanding to), dan bahkan kalkulus dianggap sebagai pelajaran (mata kuliah) yang sangat sulit untuk dipelajari, membosankan, dan subjek yang abstrak (Zhang, 2003; Zhou, 2002). Mudah frustasi dalam menghadapi masalah, tidak mengerti makna symbol yang digunakan, dan tidak cermat memanifulasi variabel x yang berupa penyebut (Mirza, 2019).

Untuk dapat menghasilkan guru yang profesional, institusi pendidik calon guru perlu membekali mahasiswa dengan berbagai teori, metode, dan keterampilan. Sementara itu, sekolah menyediakan kelas dan kurikulum, serta calon guru sendiri harus melakukan usaha individual. Lembaga Pendidikan Tenaga Kependidikan (LPTK) sebagai penghasil sarjana pendidikan tentu memiliki andil besar dalam melahirkan calon guru-guru berkualitas. Guru yang berkualitas adalah guru yang memiliki berbagai kompetensi untuk menjalankan dan melaksanakan tugasnya sebagai pendidik. Untuk itu, LPTK harus selektif dalam melaksanakan perannya sebagai filter penghasil calon guru, dengan mendorong sistem perkuliahan yang dapat meningkatkan kapasitas keterampilan profesional termasuk keterampilan berpikir tingkat tinggi (Higher Order Thinking Skills - HOTS).

Fokus pengembangan kompetensi pembelajaran matematika menghadapi abad 21 ini lebih ditekankan pada kecakapan matematis yang mencakup pemahaman konsep, kelancaran prosedur, dan pemecahan masalah serta pada keterampilan proses (daya matematis) yang mencakup kemampuan penalaran, komunikasi, koneksi, representasi dan proses pemecahan masalah (NCTM, 2000; Toh \& Kaur, 2016).

Pada kenyataannya, sistem perkuliahan atau proses pembelajaran yang dilakukan untuk membina mahasiswa calon guru matematika pada program studi pendidikan 
Vol 1 No 22020 Desember 2020

Jurnal AlphaEuclidEdu

Received: 25/11/2020; Revised: 30/11/2020; Accepted: 05/12/2020

matematika FKIP Untan masih cenderung dilakukan secara konvensional yaitu dengan pembelajaran tatap muka di dalam kelas. Dengan sistem pembelajaran seperti itu, ketika dosen tidak bisa hadir di kampus maka kegiatan pembelajaran tidak dapat dilaksanakan, ataupun ketika seorang mahasiswa berada di luar kampus maka mahasiswa tersebut tidak dapat mengikuti kegiatan pembelajaran. Sistem informasi pembelajaran online yang tersedia hanya dimanfaatkan dalam rangka untuk menyampaikan tugas dan materi pembelajaran yang perlu dipelajari secara mandiri.

Munculnya kasus Covid-19 yang terjadi memasuki awal tahun 2020 sekarang ini, membuat banyak perubahan baik di tingkat internasional maupun di tingkat nasional, bahkan lokal. Khusus di bidang pendidikan, Menteri Pendidikan dan Kebudayaan Republik Indonesia telah mengeluarkan instruksi dalam rangka Pencegahan virus Corona di Satuan Pendidikan, di antaranya dengan mengeluarkan Surat Edaran Nomor 36962/MPK.A/HK/2020 agar seluruh kegiatan belajar mengajar baik di sekolah maupun kampus perguruan tinggi menggunakan moda daring (dalam jaringan) alias online. Hal ini dimaksudkan sebagai upaya pencegahan terhadap perkembangan dan penyebaran Coronavirus disease (Covid-19). Untuk itu, beberapa lembaga pendidikan termasuk program studi pendidikan matematika FKIP Untan Pontianak harus melakukan antisipasi terhadap penyebaran virus ini dengan menyelenggarakan kuliah jarak jauh berbentuk 'online learning' atau 'belajar dalam jaringan' (belajar daring) dan berbantuan edmodo.

Pembelajaran sistem daring ini sebenarnya bukanlah hal baru. Banyak program aplikasi yang berbasis Learning Management System (LMS) yang telah dikembangkan untuk keperluan pendidikan/pembelajaran dan bahkan gratis seperti google meet, edmodo, dan lain-lain. Apalagi saat ini, perkembangan teknologi dan informasi semakin pesat. Kemajuan teknologi dalam sistem informasi melalui dunia digital seperti internet semakin mempermudah setiap orang dalam mengakses berbagai persoalan dan fenomena yang terjadi di dunia. Hal ini tentu membutuhkan kemandirian dari pemelajar dalam belajarnya. Namun demikian, realitas di lapangan menunjukkan bahwa proses pembelajaran yang memanfaatkan fasilitas teknologi tersebut belum banyak dilakukan. Akibatnya, timbul berbagai persoalan yang dihadapi ketika proses pembelajaran memaksa untuk menggunakan sistem online (sistem daring). 
Vol 1 No 22020 Desember 2020

Jurnal AlphaEuclidEdu

Received: 25/11/2020; Revised: 30/11/2020; Accepted: 05/12/2020

Pembelajaran dalam jaringan dapat digunakan sebagai alternatif solusi ketika kegiatan pembelajaran tatap muka tidak dapat dilaksanakan sebagaimana mestinya. Pembelajaran dalam jaringan dapat dilakukan melalui aktivitas belajar synchronous misalnya melalui video-converencellive-chat, ataupun secara asynchronous melalui kegiatan pembelajaran yang telah dirancang dalam sistem pembelajaran online (Tafqihan, 2011).

Substansi pembelajaran yang disampaikan dalam sistem jaringan harus sesuai dengan substansi pembelajaran tatap muka, seperti tujuan pembelajaran, konten, kesesuaian dengan kurikulum dan silabus dan perancangan pembelajaran. Untuk itu, perlu dikembangkan suatu sistem pembelajaran yang dapat mengakomodasi kegiatan pembelajaran sistem daring tanpa mengurangi substansi pembelajaran tatap muka. Materi yang akan disampaikan dengan moda daring harus sesuai dengan materi yang disampaikan dengan sistem tatap muka. Selain itu, media pembelajaran sistem daring juga harus bisa memfasilitasi mahasiswa untuk terlibat aktif dalam membangun pengetahuannya melalui forum diskusi. Pada akhirnya, evaluasi pelaksanaan pembelajaran juga dapat diukur dengan assessment yang sesuai.

Memperhatikan hal-hal yang telah diuraikan, perlu pengkajian lebih lanjut mengenai dampak dari pelaksanaan pembelajaran/perkuliahan dengan sistem daring berbantuan edmodo yang dilakukan pada program studi pendidikan matematika FKIP Untan Pontianak. Penelitian ini dilakukan dengan tujuan untuk mengetahui dan mendeskripsikan efek dari pelaksanaan pembelajaran dengan sistem daring berbantuan edmodo terhadap kemandirian belajar dan hasil belajar mahasiswa program studi pendidikan matematika FKIP Untan, serta mengetahui respon mahasiswa terhadap pelaksanaan sistem pembelajaran tersebut.

Melalui penelitian ini diharapkan dapat diketahui kebutuhan belajar mahasiswa dalam sistem pembelajaran daring berbantuan edmodo. Selanjutnya, temuan ini dapat dijadikan sebagai bahan kajian untuk mengembangkan model pembelajaran daring berbantuan edmodo yang efektif dan dapat mendukung kelancaran dalam proses perkuliahan mahasiswa pada program studi pendidikan matematika FKIP Untan Pontianak. 
Vol 1 No 22020 Desember 2020

Jurnal AlphaEuclidEdu

Received: 25/11/2020; Revised: 30/11/2020; Accepted: 05/12/2020

\section{Metode Penelitian}

Seperti telah diungkapkan di bagian pendahuluan bahwa tujuan penelitian ini adalah untuk mengkaji dan mendeskripsikan efek dari penerapan sistem pembelajaran daring berbantuan edmodo pada mahasiswa program studi pendidikan matematika FKIP Untan pada semester genap tahun akademik 2019/2020. Fokus penelitian ini adalah mengkaji: (1) Apakah sistem pembelajaran daring berbantuan edmodo dapat meningkatkan kemandirian belajar mahasiswa? (2) Apakah sistem pembelajaran daring berbantuan edmodo dapat meningkatkan hasil belajar mahasiswa? Dan (3) Bagaimana respon mahasiswa program studi pendidikan matematika FKIP Untan terhadap pelaksanaan perkuliahan dengan sistem pembelajaran daring berbantuan edmodo?

Karena itu, penelitian ini dapat dikategorikan sebagai studi kasus yang bersifat deskriptif (Arikunto, 2010; Bogdan \& Biklen, 2007), yakni bermaksud mengetahui keadaan mengenai kemandirian belajar, hasil belajar, dan respon mahasiswa pada program studi pendidikan matematika FKIP Untan mengenai pelaksanaan perkuliahan dengan sistem pembelajaran daring berbantuan edmodo. Subyek penelitian ini melibatkan 142 mahasiswa program studi pendidikan matematika yang memprogramkan mata kuliah kalkulus diferensial tahun akademik 2019/2020.

Prosedur penelitian ini terdiri dari lima tahapan. Tahap pertama: mengkaji materi, mempersiapkan alat dan instrumen penelitian (pengembangan dan pembakuan instrumen). Tahap kedua: Melaksanakan pembelajaran dengan sistem daring berbantuan edmodo. Tahap ketiga: Menyebarkan kuesioner, memberikan tes hasil belajar, dan Memberikan angket untuk mendapatkan respon mahasiswa terhadap pembelajaran yang dilakukan. (pengambilan data). Tahap keempat: Melakukan kajian dan interpretasi terhadap data yang diperoleh. Tahap kelima: Tahap pelaporan. Kegiatan penelitian ini dalam prosesnya melibatkan tiga orang mahasiswa sebagai kolaborator (pembantu peneliti), dan lima orang dosen pendidikan matematika FKIP Untan yang bertindak sebagai validator terhadap instrumen penelitian yang digunakan.

Untuk mendapatkan data mengenai kemandirian belajar dilakukan dengan menggunakan kuesioner. Indikator yang digunakan untuk mendapatkan data ini mencakup kebutuhan belajar, yang meliputi kesulitan belajar yang dialami, bahan yang dipelajari, usaha yang dilakukan, bantuan belajar yang digunakan, frekwensi melakukan 
Vol 1 No 22020 Desember 2020

Jurnal AlphaEuclidEdu

Received: 25/11/2020; Revised: 30/11/2020; Accepted: 05/12/2020

kegiatan belajar, waktu yang digunakan untuk belajar, jenis bahan ajar pendukung yang digunakan, dan kebutuhan lainnya yang diperlukan mahasiswa.

Data hasil belajar diperoleh dari nilai yang diberikan oleh dosen mata kuliah kalkulus diferensial. Sedangkan data respon didapatkan melalui angket berupa tes dengan skala likert yang terkait dengan sikap, persepsi, perasaan dan pendapat mereka mengenai pembelajaran sistem daring berbantuan edmodo.

Data dalam penelitian ini terdiri dari data kualitatif (data kemandirian belajar), dan data kuantitatif (hasil belajar dan respon). Analisis data kualitatif dijabarkan dengan kata-kata yang disusun dan disajikan dalam bentuk teks naratif. Sedangkan data kuantitatif yang diperoleh dari angket (berupa respon/tanggapan mahasiswa), diolah dengan menggunakan analisis skala Likert. Selanjut, untuk hasil belajar akan dideskripsikan dengan menggunakan persentase dan diagram batang.

\section{Hasil dan Pembahasan}

Setelah melaksanakan proses pembelajaran (perkuliahan) untuk mata kuliah kalkulus diferensial pada empat kelas, yakni kelas A1, A2, A3, dan kelas B dengan menggunakan sistem daring dan berbantuan edmodo, diperoleh hasil sebagai berikut.

\subsection{Kemandirian Belajar}

Paradigma belajar saat ini telah mengalami perubahan yang signifikan. Proses belajar tidak lagi harus dilakukan dan berlangsung dalan ruang dan waktu tertentu dan disertai kehadiran dosen. Perkembangan ilmu pengetahuan dan teknologi telah membawa sistem belajar mandiri (kemandirian belajar) sebagai kebutuhan individu untuk meningkatkan pengetahuan/keterampilan yang diperlukan. Sistem belajar mandiri ini merupakan alternatif sistem pendidikan yang bersifat luwes dengan kegiatannya dapat fleksibel (Ravet dan Laytee, 1997). Penerapan konsep belajar mandiri tidak berarti mengharuskan pemelajar untuk belajar sendiri, tetapi belajar secara terstruktur dengan menggunakan bahan ajar (learning materials) yang telah dirancang untuk keperluan tersebut. Bahan ajar ini merupakan medium yang digunakan untuk menyampaikan materi perkuliahan kepada mereka. Aktivitas belajar mandiri ini memiliki kaitan yang erat dengan pengendalian kegiatan belajar yang dilakukan oleh 
Vol 1 No 22020 Desember 2020

Jurnal AlphaEuclidEdu

Received: 25/11/2020; Revised: 30/11/2020; Accepted: 05/12/2020

individu (mahasiswa) itu sendiri, yakni pembelajaran yang berpusat pada pemelajar/peserta didik (France \& Jordan, 2000).

Dari data yang diperoleh, kemandirian belajar 142 mahasiswa dalam perkuliahan kalkulus diferensial masih belum memuaskan, karena:

a) Mahasiswa umumnya tidak terbiasa belajar sebelum mengikuti perkuliahan

b) Mahasiswa memiliki frekwensi belajar yang relatif rendah dalam mempelajari mata kuliah kalkulus diferensial, dan tidak terbiasa memanfaatkan sumber belajar lain selain buku/bahan ajar yang diberikan

c) Mahasiswa pada umumnya kurang berusaha untuk mencari sumber belajar lain selain dari buku/bahan ajar yang diberikan untuk menambah dan mengembangkan pengetahuan serta keterampilannya.

d) Mahasiswa mengemukakan bahwa mereka jarang mendapat umpan balik yang memberikan penjelasan tentang hasil belajar yang diperoleh.

\subsection{Hasil Belajar}

Hasil belajar mahasiswa berdasarkan nilai akhir mata kuliah yang diperoleh dari rekap sistem akademik di FKIP Untan (Siakad) menunjukan Kelas A1 (nilai A=12 orang, $\mathrm{B}=12$ orang, $\mathrm{C}=3$ orang); Kelas $\mathrm{A} 2$ (nilai $\mathrm{A}=2$ orang, $\mathrm{B}=33$ orang, $\mathrm{C}=11$ orang), Kelas $\mathrm{A} 3$ (nilai $\mathrm{A}=9$ orang, $\mathrm{B}=9$ orang, $\mathrm{c}=2$ orang) dan Kelas $\mathrm{B}$ (nilai $\mathrm{A}=1$ orang, $\mathrm{B}=28$ orang, $\mathrm{C}=20$ orang). Jadi secara keseluruhan, yang mendapat nilai $\mathrm{A}=24$ orang, nilai $\mathrm{B}=82$ orang, dan nilai $\mathrm{C}=36$ orang. Frekwensi dari 142 mahasiswa berdasarkan perolehan hasil belajar ini dapat digambarkan dalam bentuk diagram batang sebagai berikut.

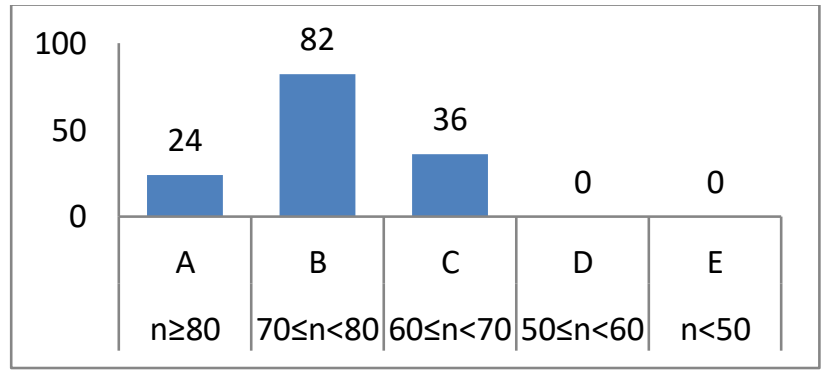

Gambar 4.1. Frekwensi Mahasiswa Berdasarkan Perolehan Hasil Belajar

3.3. Respon Mahasiswa 
Vol 1 No 22020 Desember 2020

Jurnal AlphaEuclidEdu

Received: 25/11/2020; Revised: 30/11/2020; Accepted: 05/12/2020

Respon Mahasiswa terhadap pembelajaran, berdasarkan jawaban dari 25 item angket respon setelah dilakukan pembobotan, diperoleh jumlah skor dan skor rata-rata dari masing-masing responden. Berdasarkan data ini selanjutnya dihitung frekwensi dan persentase respon untuk mendapatkan table interval respon yang dijadikan sebagai indikator respon mahasiswa terhadap sistem pembelajaran daring berbantuan edmodo yang dilakukan dalam penelitian ini. Berdasarkan data tersebut, 81 orang mahasiswa $(57,04 \%)$ memberikan respon positip, dan 61 (42,96\%) memberikan respon negatip.

Kriteria yang digunakan untuk menentukan kategori respons mahasiswa terhadap sistem pembelajaran daring berbantuan edmodo pada mata kuliah kalkulus diferensial dalam penelitian ini adalah mengacu pada tabel interval dari skala sikap/persepsi sebagai berikut.

Tabel 4.1.

Interval Skor Respon Mahasiswa Terhadap Perkuliahan Dengan

Sistem Pembelajaran Daring Berbantuan Edmodo

\begin{tabular}{|c|c|}
\hline Interval & Respon \\
\hline $0,00-0,45$ & Sangat Negatif \\
\hline $0,46-1,33$ & Negatif \\
\hline $1,34-2,19$ & Positif \\
\hline $2,20-2,70$ & Sangat Positif \\
\hline
\end{tabular}

Hasil tersebut menunjukkan bahwa persentase respon mahasiswa terhadap perkuliahan sistem daring berbantuan edmodo setelah dilakukan pembobotan skor butir respon masih cukup berimbang. Walaupun secara kuantitas, respon mahasiswa menunjukkan respon yang positip, namun hal ini masih kurang memuaskan karena tidak ada yang memberikan respon yang "sangat positif". Sebaliknya sistem perkuliahan tersebut tidak juga memberikan respon yang tidak baik, karena tidak ada yang memberikan respon "sangat negatip". Dengan demikian, model perkuliahan dengan sistem daring dan berbantuan edmodo masih dapat diterima sebagian besar mahasiswa.

Terkait dengan respon negatip yang diberikan mahasiswa, tampaknya lebih dominan diakibatkan karena adanya gangguan atau hambatan lain yang bersifat non teknis pembelajaran. Gangguan atau hambatan tersebut seperti perlunya biaya pembelian fulsa/quota internet, jaringan internet yang tidak mendukung, dan aliran listrik yang terganggu (mati), serta ada juga yang terhambat karena persoalan perangkat yang tidak memadai. Hal ini membuat mahasiswa menjadi bingung, kecewa dan membebaninya. 
Vol 1 No 22020 Desember 2020

Jurnal AlphaEuclidEdu

Received: 25/11/2020; Revised: 30/11/2020; Accepted: 05/12/2020

\subsection{Tantangan Yang Dihadapi Dalam Pembelajaran Sistem Daring}

Ada berbagai pandangan mengenai pengertian belajar dalam jaringan (daring). Dalam Kamus Besar Bahasa Indonesia, Daring diartikan dalam jaringan, terhubung melalui jejaring computer, internet dan sebagainya. Menurut Sutrisno (2020), rangkuman sistematis tentang pengertian belajar dalam jaringan telah dibuat oleh Vandana Singh dan Alexander Thurman pada tahun 2019. Hasil analisis isi (content analysis) yang dilakukan mereka tentang definisi belajar dalam jaringan yang digunakan dalam kurun waktu 1988-2018 menemukan ada 37 rumusan yang saling berbeda. Di sini, perbedaan rumusan tersebut tidak perlu diperdebatkan. Akan tetapi, yang penting diperhatikan adalah sisi positipnya saja, apapun bentuk atau sistem pembelajaran daring yang digunakan. Lebih lanjut Sutrisno (2020) menyatakan bahwa Universitas Purdue Internasional mengungkap empat tantangan yang umum dihadapi oleh para pemelajar dalam jaringan, terutama bagi mereka yang belum terbiasa atau belum ernah bekerja dalam jaringan. Tantangan-tantangan itu adalah sebagai berikut: (1) literasi digital, (2) masalah teknis, (3) pengelolaan waktu, dan (4) motivasi.

Tantangan 1 : literasi digital

Untuk mengikuti kelas daring, diperlukan kemampuan menggunakan teknologi yang memadai untuk: ' $\log$ in', berpartisipasi, berkomunikasi dalam kelas dan menyerahkan tugas. Kemampuan ini mencakup pemahaman etika komunikasi dalam jaringan serta pengetahuan tentang hak dan kewajibannya sebagai pembelajar dalam jaringan. Untuk menangani tantangan itu disarankan agar memperhatikan sungguh-sungguh apa yang dikehendaki instructor/dosen tentang apa yang harus dilakukan. Ada beberapa yang perlu diingat tentang etika berkomunikasi dalam jaringan, seperti menghindari penggunaan kata sakartik (kasar), komentar dan pertanyaan yang tidak relevan.

Tantangan 2 : masalah teknis

Sebagai pemelajar dalam jaringan, hanya akan berhasil jika berhasil terhubung kapan pun dan dimana pun. Karena itu, mesti tersedia kuota dan koneksi internet yang kuat (memadai). Masalah ini tidak semua orang mampu menyelesaikan karena berkaitan dengan dana yang tersedia.

Tantangan 3 : pengelolaan waktu

Pembelajaran secara daring membutuhkan kesadaran individu untuk mau mengatur waktu dalam beraktivitas. Kelemahan dalam mengelola atau mengatur waktu secara 
Vol 1 No 22020 Desember 2020

Jurnal AlphaEuclidEdu

Received: 25/11/2020; Revised: 30/11/2020; Accepted: 05/12/2020

baik dapat menjadi sebab yang membebani dalam melaksanakan tugas belajar yang diberikan.

Tantangan 4 : kedisiplinan dan motivasi

Belajar daring perlu motivasi diri yang kuat untuk dapat menyelesaikan tugas tepat waktu. Akibat tidak ada interaksi (tidak berkumpul) dengan rekan-rekan sekelas secara fisik, seringkali memunculkan godaan pada diri untuk menunda pekerjaan.

\section{Kesimpulan}

Berdasarkan data yang diperloleh dari hasil penelitian ini, maka dapat dibuat kesimpulan sebagai berikut:

1) Kemandirian belajar

Terkait dengan kemandirian belajar, dapat disimpulkan bahwa para mahasiswa umumnya tidak terbiasa untuk belajar (mempelajari materi) sebelum mengikuti program perkuliahan. Frekwensi belajar yang dilakukan mahasiswa masih rendah. Masih banyak mahasiswa yang tidak memanfaatkan sumber belajar lainnya selain bahan ajar atau materi yang diberikan dosen, untuk menambah wawasan pengetahuan dan keterampilannya agar mencapai kemampuan/keterampilan berpikir tingkat tinggi (higher order thinking skills).

Mahasiswa lebih cenderung memerlukan pengetahuan yang bersifat praktis agar dapat digunakan dalam menyelesaikan masalah/soal yang terkait materi yang dipelajari. Dalam hal ini, mereka umunya kurang serius untuk memahami hal-hal yang bersifat analitis, sehingga mereka mengganggap buku-buku atau referensi yang tersedia sangat bersifat teoritis.

2) Hasil Belajar

Berdasarkan data hasil belajar 142 mahasiswa yang menjadi subyek penelitian, didapatkan bahwa 74,65\% mahasiswa mampu mencapai skor $\geq 70$, yakni : 57,75\% mendapat nilai B dan 16,90\% mendapat nilai A. Sisanya, Nilai C 25,3\%, sedangkan nilai $\mathrm{D}$ dan $\mathrm{E}$ tidak ada. Data ini menunjukkan bahwa pembelajaran dengan sistem daring berbantuan edmodo ternyata masih mampu memberikan kontribusi yang cukup baik bagi keberhasilan mahasiswa dalam mengikuti dan menguasai materi perkuliahan kalkulus diferensial.

3) Respon Mahasiswa 
Vol 1 No 22020 Desember 2020

Jurnal AlphaEuclidEdu

Received: 25/11/2020; Revised: 30/11/2020; Accepted: 05/12/2020

Berdasarkan data 142 mahasiswa yang dijadikan subyek analisis dalam penelitian ini, diperoleh: 81 orang $(57,04 \%)$ memberikan respon positip terhadap sistem perkuliahan daring berbantuan edmodo, sisanya 61 orang $(42,96 \%)$ memberikan respon yang negatif, dan tidak ada responden yang memberikan respon untuk kategori sangat negatif ataupun sangat positip. Hal ini menunjukkan bahwa pembelajaran sistem daring berbantuan edmodo masih dianggap cukup baik. Namun demikian, ada tantangan yang harus dihadapi dan diantisipasi ketika berhadapan dengan sistem pembelajaran daring, yakni tantangan literasi digital, masalah teknis, pengelolaan waktu, dan (4) motivasi.

Kiranya, pengkajian yang lebih mendalam untuk masalah penelitian semacam ini masih perlu dilakukan untuk mendapatkan data dan informasi yang lebih akurat. Selanjutnya, perlu dikembangkan desain perkuliahan (desain pedagogik) yang dapat memfasilitasi belajar mahasiswa dengan sistem daring yang lebih berkualitas dan mudah dilakukan agar tercipta kualitas proses perkuliahan maupun kualitas kompetensi profesional dan pedagogik pada diri mahasiswa, khususnya pada mahasiswa pendidikan matematika di lingkungan FKIP Untan.

\section{Referensi}

AACTE. (2010). 21 ${ }^{\text {st }}$ Century knowledge and skills an educator preparation. The American Association of Colleges of Teacher Education and the Partnership for $21^{\text {st }}$ Century Skills (P21). http://www.p21.org/storage/documents/ aacte_p21_whitepaper2010.pdf. Diakses 9 Februari 2015

Acharya, B. R. (2017). Factors Affecting Difficulties in Learning Mathematics by Mathematics Learners. International Journal of Elementary Education, 815.

Arikunto, S. (2010). Prosedur Penelitian: Suatu Pendekatan Praktek, Edisi Revisi. Jakarta: Rineka Cipta.

Bersin, J. (2011). Blended learning: Research reports \& examples of best practices. Estonia: B-Learn Project University of Tartu.

Bogdan, R.C. \& Biklen, S.K. (2007). Qualitative Research for Education: An Introduction to Theory and Methods $5^{\text {th }}$.ed. Boston: Allyn \& Bacon.

France, B \& Jordan, D.H. (2000). Evaluation and Implementation of Distance Learning: Technologies, Tools and Technique. UK: Idea Group Publishing.

Halpern, D. F. (2003). Thought and knowledge: An introduction to critical thinking (4 ${ }^{\text {nd }}$ Edition). New Jersey: Lawrence Erlbaum Associates Publisher

King, F. J., Goodson, L., \& Rohani. (2006). Higher order thinking skills. Center for Advancement of Learning and Assessment.

Mirza, Ade. (2019). Hambatan Belajar Mahasiswa Program Studi Pendidikan Matematika FKIP Untan Dalam Mata Kuliah Kalkulus Diferensial. Laporan Penelitian. Pontianak: FKIP Untan. 
Vol 1 No 22020 Desember 2020

Jurnal AlphaEuclidEdu

Received: 25/11/2020; Revised: 30/11/2020; Accepted: 05/12/2020

Moseley, D., Baumfield, V., Elliot, J., Gregson, M., Higgins, S., Miller, J., \& Newton, D. (2005). Frameworks for thinking: A handbook for teaching and learning. New York: Cambridge University Press.

National Council of Teacher of Mathematics (NCTM). (2000). Principles and Standards for School Mathematics. Reston, VA: NCTM.

Ravet, S. \& Laytee, M. (1997). Technology-Based Training: A Comprehensive Guide to Choosing, Implementing, Managing, and Developing Technologies in Training.

Sutrisno, L. (2020). Belajar dalam Jaringan. https://teraju.id/opini/darurat-pembelajarandalam-jaringan-di-perguruan-tinggi-12716/ diakses tgl 14 Maret 2020.

Tafqihan, Z. (2011). Karakteristik dan Pemilihan Media Pembelajaran dalam ELearning. Jurnal Cendekia Volume 2 Nomor 9 tahun 2011, hal: 141154,ISSN: 2477-796X.

Toh P. Choon \& Kaur, B. (2016). Developing 21st Century Competencies In The Mathematics Classroom. Yearbook 2016, Association of Mathematics Educators. Singapore: World Scientific Publishing Co. Pte. Ltd.

Zhang, B. (2003). Using student centered teaching strategis in calculus. In M. Peat (ed.) The China Papers: Tertiary Science and Mathematics Teaching for the 21st Century, 2: 100-103.

Zhou Yuan, (2002). Improving the qualities of teaching calculus - by modern education theories and modern technology, In M. Peat (ed.) The China Papers: Tertiary Science and Mathematics Teaching for the 21st Century, 1: 23-27.

Zohar, A., Degani, A \& Vaaknin, E. (2001). Teachers' beliefs about low-achieving students and higher order thinking. Teaching and Teacher Education, 17: 469485 